UDC58.006: 581.526 .422

DOI 10.37555/2707-3114.1.2021.247456

\title{
Forest Vegetation Cover in Yok Don National Park, Vietnam
}

\author{
Dang Viet Hung ${ }^{1}$, Dang Thi Lan Anh ${ }^{1}$, Nguyen Thi Ha ${ }^{1}$, Alexander F. Potokin ${ }^{2}$, Vu Van Truong ${ }^{3}$ \\ ${ }^{1}$ Department of Forest Plant, Vietnam National University of Forestry - Dong Nai Campus, Vietnam, Dong Nai Province, Trang Bom \\ District, Trang Bom town, Tran Phu st., 54, e-mail: viethung@vnuf2.edu.vn \\ ${ }^{2}$ Department of Botany and Dendrology, Saint-Petersburg State Forest Technical University, 5U, Instytutskiy, St. Petersburg 194021, \\ Russian Federation, e-mail: alex221957@mail.ru \\ ${ }^{3}$ Department of Environmental Management, Vietnam National University of Forestry, Xuan Mai, Chuong My, Ha Noi, Vietnam, \\ e-mail: vantruongvu042003@gmail.com
}

\section{Лісова рослинність національного парку Йок-Дон, В’єтнам}

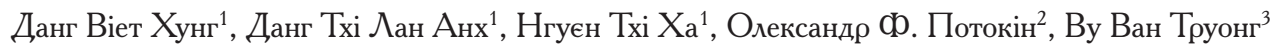 \\ ${ }^{1}$ Кафедра лісових рослин, Наџіональний університет лісового господарства, м. Транг Бом, В'єтнам, e-mail: viethung@vnuf2.edu.vn \\ ${ }^{2}$ Кафедра ботаніки та дендрології, Санкт-Петербурзький державний лісотехнічний університет, м. Санкт-Петербург, РФ, е-mail: \\ alex221957@mail.ru \\ ${ }^{3}$ Кафедра екологічного менеджменту, Наџіональний університет лісового господарства, м. Транг Бом, В'єтнам, е-mail: \\ vantruongvu042003@gmail.com
}

Abstract. Yok Don National Park is located in the tropical rainforest zone on the Central Highlands of Vietnam. The obtained results from the study undertaken on the composition of plant species and forest vegetation in National Park indicated a record of 856 species, 473 genera and 129 families that belongs to the four divisions of vascular plants. These includes: Lycopodiophyta, Polypodiophyta, Pinophyta and Magnoliophyta. Useful plants of 856 taxonomy species listed consists of 498 species of medicinal plants, 157 species of timber plants, 144 species of edible plants, 60 species of ornamental plants, 19 species of industrial plants, 10 species of fiber plants and 38 species of unknown use plants, respectively. During the duration of investigation, Peliosanthes teta Andrews was newly recorded in the forest vegetation of National Park. A variety of forest vegetations in the area under study is described. In this study, four major vegetation types of forest were identified in Yok Don National Park.

Key words: forest ecosystems, geobotanical and floristic study, Peliosanthes teta Andrews, useful plants, variety of forest vegetations, vascular plants.

Анотація. Мета. Вивчення лісового рослинного покриву Наџіонального парку Йок-Дон, розташованого у зоні тропічних лісів на Џентральному високогір'ї В'єтнаму. Матеріали і методи. Лісову рослинність наџіонального парку Йок-Дон досліджували загальновживаними методами. Результати та обговорення. Дослідження видового складу рослинності та лісових рослин у Наџіональному парку дали змогу ідентифікувати 856 видів з 473 родів та 129 родин, які належать до чотирьох відділів судинних рослин. До них відносять: Lycopodiophyta, Polypodiophyta, Pinophyta та Magnoliophyta. За ознаками корисності список 856 видів рослин включає: 498 видів лікарських, 157 деревних, 144 їстівних, 60 декоративних, 19 технічних, 10 видів волокнистих рослин та 38 видів невизначеного використання. У проџесі обстеження лісової рослинності парку знову було зареєстровано Peliosanthes teta Andrews. Описується різноманіття виявленої на досліджуваній території лісової рослинності. Висновки. Унаслідок виконаних досліджень у Наџіональному парку Йок-Дон було виявлено чотири основні типи лісової рослинності: тропічний широколистяний диптерокарповий, тропічний вічнозелений широколистяний, тропічний напів-вічнозелений широколистяний та змішаний ліс. Отримана інформаџія сприятиме збереженню та сталому розвитку Наџіонального парку. Окрім корисних рослин у парку було зафіксовано чотири ендемічні види та 16 видів, які підлягають збереженню на глобальному та наџіональному рівнях. 
Ключові слова: лісові екосистеми, геоботанічні та флористичні дослідження, Peliosanthes teta Andrews, корисні рослини, різноманіття лісової рослинності, судинні рослини.

Introduction. In accordance with Decision № 352/CT of 29/10/1991, Yok Don National Park (hereafter YDNP) was recognized as a specially protected natural area of Vietnam by the Prime Minister of the Republic of Vietnam (Nguyen Viet Luong et al, 2017). The object of study is located in Dak Lak province, with an area of 115545 ha, between 12045\&apos; - 13010\&apos; north latitude and 107029\&apos; - 107048\&apos; east longitude (fig. 1).

Figure 1. Yok Don National Park located in Dak Lak province
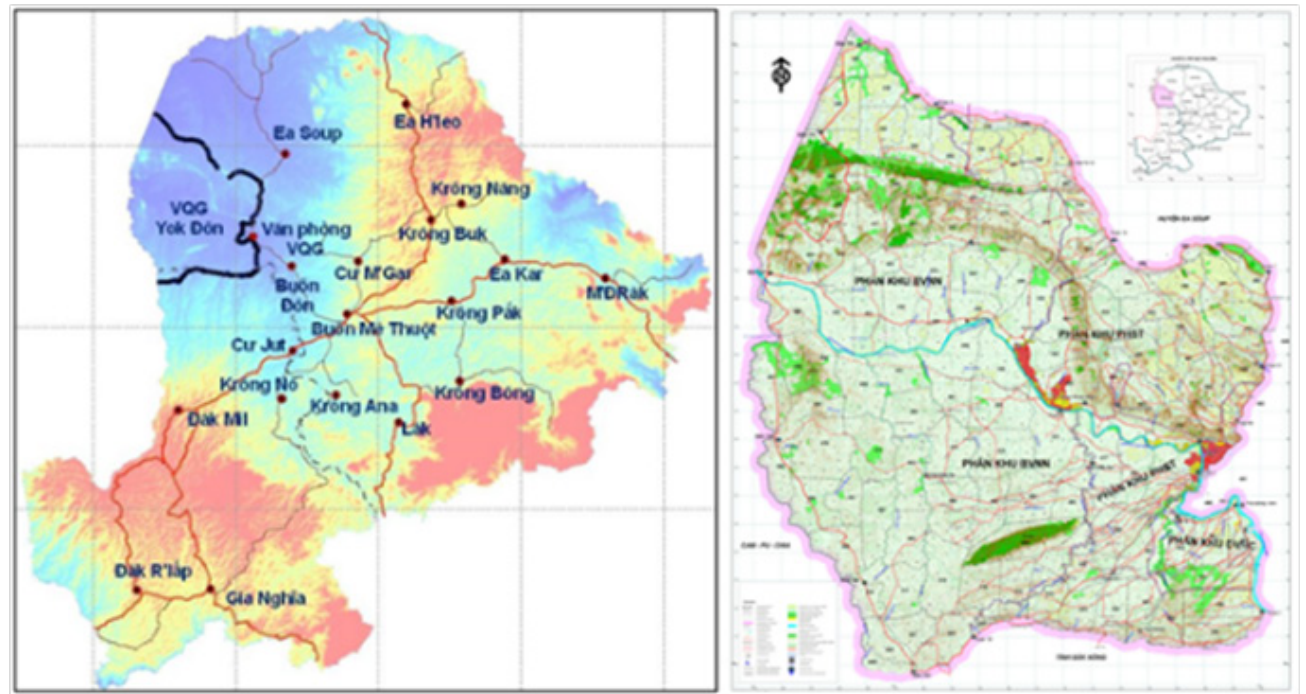

The forest vegetation at Yok Don National Park is dominated by a mosaic of deciduous forest and semi-evergreen (mixed deciduous) forest, with smaller areas of evergreen forest, particularly on hills and along watercourses. 856 vascular plant species have been recorded in National Park. YDNP is the only remaining natural of deciduous dipterocarp forest, located on the central highland of Vietnam. Rare, valuable and endemic species of flora and fauna, listed in the Red Book of Vietnam (2007) and the International Union for Conservation of Nature (IUCN, 2002), live in YDNP. However, in recent years, the structure of forest vegetation cover in YDNP has changed. This led to a change in the habitat of plants and animals, the number of individuals decreased, and many rare and endangered species were threatened. Therefore, the issue of forest conservation in YDNP plays an important role.

Materials and Methods. The objects for research were forest ecosystems on the territory of YDNP. Ecological and geographical analysis of the species composition of forests in the National Park indicates certain links between regions and environmental conditions reveals their environmental specificity. Geobotanical and floristic study was carried out on the 25 plots $(20 \times 20 \mathrm{~m})($ Nguyen \& Baker, 2016). We established 8 transects, which covered the whole surface area of YDNP. The total length of these transects combined is about $15 \mathrm{~km}$. In each transect we marked all species and collected specimens of plants which could not be identified in the field. We also collected many plants outside the plots and traverses, to make sure that our inventory was as representative of the entire area with species of the local flora (Hoang Van Sam, Baas \& Keßler, 2008b).

Voucher species were sent to the Herbarium of Vietnam National University of Forestry - Dong Nai campus and other specialists for identification. Plant species were identifed with reference to An Illustrated of Flora of Vietnam (Pham, 1999).

The vegetation types of YDNP were classified according to Thai Van Trung (Thai, 1999). Additionally, the human disturbance levels of the vegetation were determined by noting the number of tree stumps and number of foot paths in the plots (Nguyen \& Baker, 2016).

From 10/2020-2/2021, the research team conducted many surveys in Ea Po, Dak Wil, Ea Bung, Chư M'Lan, Krong $\mathrm{Na}$, Ea Huar and Ea Wer villages in YDNP. Field research was conducted to gain intensive understanding of people through 
discussions and interactions. Primary data was gathered initially through household interviews based on questionnaires, Rapid Rural Appraisal (RRA), and the "walk in the woods" method (Kovyazin at el, 2020; Van, Cochard, 2017).

Results and discussion. Vegetation types in YDNP. The vegetation of YDNP is dominantly lowland forest type with the highest peak level of about $502 \mathrm{~m}$ (Thai, 1999). Among the natural vegetations of YDNP there is a major dichotomy between the evergreen forests on lowland types and other types of formations. The composition of the vegetation in YDNP is identified by 4 major types: deciduous dipterocarp forest, tropical evergreen broad-leaved forest, tropical evergreen broad-leaved semi-deciduous and mixed forest.

Deciduous dipterocarp forest or deciduous forest. This forest type covers about 106685,8 ha and it takes $96 \%$ of the total area of National Park. The following species, such as: Dipterocarpus tuberculatus, Dipterocarpus obtusifolius, Dipterocarpus intricatus, Shorea siamensis, Terminalia tomentosa, Aporosa dioica, etc... The structure of this forest type is simple, trees lose their leaves during the long dry season; it includes the tree layer and a ground layer with mainly weedy species belonging to families Dipterocarpaceae, Combretaceae and Euphorbiaceae.

Tropical evergreen broad-leaved forest. The tropical evergreen broad-leaved forest type is the most common in the lowland forest, such as Yok Don and Yok Da mountain. Dominant families are Fagaceae, Fabaceae, Ebenaceae, Lauraceae, Meliaceae, Rubiaceae, etc... The forest structure is simple with three layers: The canopy layer is composed mainly of Afzelia xylocarpa, Pterocarpus macrocarpus, Dalberga cochinchinensis, Sindora siamensis, Parinari annamensis, Irvingia malayana, etc... The shrub layer is composed of many species, with as dominant ones Ixora delpyana, Psychotria adenophylla, Randia dasycarpa, Hyptis rhomboidea, Scoparia dulcis, Clerodendrum tonkinensis, Dracaena angustifolia, etc... The herb layer is composed mainly of species are Peliosanthes teta, Typhonium trilobatum, Asparagus cochinchinensis, Flagellaria indica, Chrysopogon aciculatus, Dactyloctenium aegyptiacum, Panicum repens, Vetiveria zizanoides, Globba pendula, Desmodium styracifolium, and some other species.

Tropical evergreen broad-leaved semi-deciduous forest. This forest type covers about 750 ha. Dominant families are Fabaceae, Meliaceae, Moraceae and Rubiaceae. The following species, such as: Dipterocarpus alatus, Lagerstroemia calyculata, Terminalia triptera, Diospyros maritima, Diospyros variegata, Syzygium chanlos, Syzygium cinereum, Syzygium tinctorium, Syzygium zeylanicum, Cratoxylon cochinchinensis, Cratoxylon formosum,...

The shrub layer includes only few species, such as Rhodamnia dumetorum, Carallia diplopetala, Memecylon caeruleum, Leea aequata, Mallotus nanus,...

The herb layer is composed mainly of species are Alpinia conchigera, Costus speciosus, Commelina communis, Typhonium trilobatum, Cissus repens, Cyclea barbata, etc...

Mixed forest. This forest type is distributed along rivers and streams. This forest type is often found in Srepok River, Dak $\mathrm{Na}$ Stream, around Dak Minh Lake, Dak Ken Lake and Dak Lau Lake. Dominant species in forest vegetation are represented by such as: Terminalia chebula, Terminalia corticosa, Mischocarpus sundaicus, Bambusa arundinacea, Oxytenanthera nigrociliata, Vietnamosasa ciliata, Vietnamosasa pusilla, Vietnamosasa darlacensis, Kaempferia galanga and Cycas pectinata.

3.2. Floristic diversity in YDNP

During our investigations, 856 vascular plant species belong to 473 genera and 129 families were identified in YDNP can be seen in Table 1. The present study recorded one new species in YDNP, named Peliosanthes teta Andrews in Convallariaceae.

Table 1. Summary on the floristics of Yok Don National Park

\begin{tabular}{|c|l|c|c|c|}
\hline No. & \multicolumn{1}{|c|}{ Taxa } & Family & Genus & Species \\
\hline 1. & Lycopodiophyta & 1 & 1 & 2 \\
\hline 2. & Polypodiophyta & 9 & 15 & 18 \\
\hline 3. & Pinophyta & 2 & 2 & 3 \\
\hline 4. & Magnoliophyta & 119 & 455 & 833 \\
\hline & Total & $\mathbf{1 2 9}$ & $\mathbf{4 7 3}$ & $\mathbf{8 5 6}$ \\
\hline
\end{tabular}

Among the investigated 856 species, 4 endemic species in Vietnam were also included. Many plant species are endemic to Vietnam (the species were first records in Vietnam and scientific names take the places of Vietnam) and endemic plants of local (the first records of species in YDNP) such as Vietnamosasa darlacensis (Table 2). 
Table 2. List of endemic plants in Yok Don National Park

\begin{tabular}{|c|l|l|c|}
\hline No. & \multicolumn{1}{|c|}{ Family name } & \multicolumn{1}{|c|}{ Scientific name } & Vietnamese name \\
\hline 1. & Apocynaceae & Telectadium dongnaiense Pierre ex Cost. & Vệ tuyền đồng nai \\
\hline 2. & Orchidaceae & Dendrobium langbianense Gagnep. & Lan lang-bi-an \\
\hline 3. & Poaceae & Vietnamosasa darlacensis T. Q. Nguyen & Le đăk lăk \\
\hline 4. & Theaceae & Camellia yokdonensis Dung \& Hakoda & Trà hoa đỏ yok đôn \\
\hline
\end{tabular}

In YDNP, useful plants of 856 species listed consists of 498 species (58.2\%) of medicinal plants (Me), 157 species $(18.3 \%)$ of timber plants $(\mathrm{Ti}), 144$ species $(16.8 \%)$ of edible plants $(\mathrm{Ed}), 60$ species $(7.0 \%)$ of ornamental plants (Or), 19 species $(2.2 \%)$ of industrial plants $(\mathrm{In}), 10$ species $(1.2 \%)$ of fiber $(\mathrm{Fi})$ and 38 species $(4.4 \%)$ of unknown use plants $\left(\mathrm{Un}_{\mathrm{n}}\right.$, respectively in Table 3.

Table 3. Usefulness of plant resources in Yok Don National Park

\begin{tabular}{|c|c|c|c|c|c|c|c|}
\hline Uses & $\mathrm{Me}$ & $\mathrm{Ti}$ & $\mathrm{Ed}$ & $\mathrm{Or}$ & $\mathrm{In}$ & $\mathrm{Fi}$ & Un \\
\hline Species & 498 & 157 & 144 & 60 & 19 & 10 & 38 \\
\hline$\%$ & 58.2 & 18.3 & 16.8 & 7.0 & 2.2 & 1.2 & 4.4 \\
\hline
\end{tabular}

The plant resources of YDNP are valuable not only because of the great diversity, but also have great environmental importance. As part of the flora of YDNP, 16 species of 856 plant species were listed in the Red book of Viet Nam (2007). In the red book of IUCN (2021), 2 species were classified as endangered species (EN), 1 species were classified as vulnerable species (VU) and 2 species were classified as least concern (Table 4).

Table 4. List of endangered and rare plants in Yok Don National Park

\begin{tabular}{|c|l|c|c|}
\hline No. & \multicolumn{1}{|c|}{ Scientific name } & VRDB (2007) & IUCN (2021) \\
\hline 1. & Afzelia xylocarpa (Kurz) Craib. & EN & EN \\
\hline 2. & Alstonia scholaris (L.) R. Br.. & LC \\
\hline 3. & Anisoptera costata Korth. & EN & \\
\hline 4. & Cycas lindstromii S. L. Yang, K. D. Hill \& N. T. Hiep & VU & VU \\
\hline 5. & Cycas pectinata Griff. & VU & EN \\
\hline 6. & Dalbergia oliveri Gamble ex Prain & EN & VU \\
\hline 7. & Drynaria bonii Christ. & EN & \\
\hline 8. & Drynaria fortunei (Kunze ex Mett.) J. Sm. & VU & \\
\hline 9. & Markhamia stipulata (Wall.) Schum. var. pierrei (Dop.) Sant. & VU & \\
\hline 10. & Melanorrhoea laccifera Pierre.. & VU & \\
\hline 11. & Melientha suavis Pierre & VU & \\
\hline 12. & Millingtonia hortensis L.f. & VU & \\
\hline 13. & Oryza rufipogon Griff. & VU & \\
\hline 14. & Peliosanthes teta Andre. & EN & EN \\
\hline 15. & Pterocarpus macrocarpus Kurz. & & LC \\
\hline 16. & Sindora siamensis Teysm. ex Miq. & & \\
\hline
\end{tabular}

Note: VRDB - Vietnam Red Data Book (2007)

IUCN - Global conservation status (2021)

EN - Endangered; VU - Vulnerable; LC-Least Concern 
Conclusions. YDNP is characterized by 4 major vegetation types of forest: deciduous dipterocarp forest, tropical evergreen broad-leaved, tropical evergreen broad-leaved semi-deciduous and mixed forest.

The diversity of plant species in YDNP was studied to provide baseline information for conservation and sustainable management processes that will prolong the the life of National Park. A total of 856 species of vascular plants are recorded in YDNP belonging to 473 genera and 129 families. From the indicated species Peliosanthes teta is new record species for the flora in YDNP.

The useful plant resources were divided into seven groups as follows: medicinal plants with 498 species, timber plants with 157 species, edible plants with 144 species, ornamental plants with 60 species, industrial plants with 19 species, fiber plants with 10 species and unknown use plants with 38 species.

Besides this survey, the forest areas were explored, concentrating on the useful plants and it was recorded that National Park has 4 endemic species, 16 species subject to global-level and national-level conservation.

\section{References}

Hoang, Van Sam, Baas, P \& Keßler, P J A (2008). The use and conservation of plant species in a National Park - A case study of Ben En, Vietnam Economic Botany 62: pp 574-593.

IUCN, (2002). Sustainable Financing Mechanisms for Yok Don National Park, PARC Project VIE/95/ G31\&031, Government of Viet Nam (FPD) /UNOPS/UNDP/IUCN, Ha Noi. 36 p.

Ministry of science and technology of Vietnam (2007). Red book. Part 2: plants. Hanoi: science and technology publishing House, p 612.

Nguyen, T T, \& Baker, P J (2016). Structure and composition of deciduous dipterocarp forest in Central Vietnam: patterns of species dominance and regeneration failure Plant Ecology \& Diversity 9(5-6), doi:10.1080/17 550874.2016.1210261 pp 589-601.

Nguyen, Viet Luong et al (2017). Land cover mapping in Yok Don National Park, Central Highlands of Viet Nam using Landsat 8 OLI images, Vietnam Journal of Earth Sciences, 39(3), 393-406

Pham, H H (1999). Cây Cỏ Việtnam [In Vietnamese - An Illustrated Flora of Vietnam] (Ho Chi Minh City: The Youth Publishing House) Vol. 1-3, pp. 202-208 \& 295-296.

Thai, V.T (1999). Những hệ sinh thái rừng nhiệt đới Việt Nam [In Vietnamese - The forest ecosystems in tropical Vietnam] (Hồ Chí Minh: NXB Khoa học và Kỹ Thuật) 298 p.

URL: https://www.iucnredlist.org/ (accessed 10 August, 2021).

Kovyazin, V.F., Demidova, P.M., Dang, Thi, Lan Anh, Dang, Viet Hung, and Nguyen, Van Quyet (2020). Monitoring of Forest Land Cover Change in Binh Chau - Phuoc Buu Nature Reserve in Vietnam Using Remote Sensing Methods and GIS techniques. IOP Conf. Ser.: Earth Environ. Sci. (507): 1-9 / doi:10.1088/1755-1315/507/1/012014.

Van, Y. T., Cochard, R. (2017). Tree species diversity and utilities in a contracting lowland hillside rainforest fragment in Central Vietnam. For. Ecosyst. 19 p. 